\title{
Mineral processing and characterization of coal waste to be used as fine aggregates for concrete paving blocks
}

\section{Processamento mineral e caracterização de rejeito de carvão mineral para produção de blocos de concreto para pavimentação}

C. R. SANTOS a

cassiano_eng@hotmail.com

R. M. C.TUBINO

rejane.tubino@ufrgs.br

I. A. H. SCHNEIDER a

ivo.andre@ufrgs.br

\begin{abstract}
Commercial coal production in the southern region of Brazil has been occurring since the beginning of the twentieth century. Due to the geological characteristics of the region, large amounts of solid wastes are generated. The aim of this work was to evaluate the use of coal waste to produce concrete paving blocks. A procedure to process the coal waste with the purpose of reducing the sulfur content and changing the particle size distribution of the material to meet the specification of fine aggregates was developed. The methodology considered the following steps: (a) sampling of a coal mining waste; (b) gravity separation of the fraction with specific gravity between 2.4 and 2.8; (c) comminution of the material and particle size analysis; (d) technological characterization of the material and production of concrete paving blocks; and (e) acidity generation prediction (environmental feasibility). The results showed that the coal waste considered in this work can be used to replace conventional sand as a fine aggregate for concrete paving blocks in a proportion of up to $50 \%$. This practice can result in cleaner coal production and reduce the demand for exploitation of sand deposits.
\end{abstract}

Keywords: coal waste, environment, fine aggregate, concrete, paving.

\section{Resumo}

A produção de carvão mineral na região sul do Brasil vem ocorrendo desde o início do século XX. Devido às características geológicas da região, grandes quantidades de resíduos sólidos são gerados. O objetivo deste trabalho foi avaliar a utilização de rejeito de carvão para a produção de blocos de pavimentação de concreto. O rejeito de carvão foi beneficiado com o objetivo de reduzir o teor de enxofre e ajustar o tamanho das partículas do material para as especificações de distribuição granulométrica de agregado miúdo. A metodologia considerou os seguintes passos: (a) amostragem do rejeito de carvão mineral; (b) separação gravimétrica da fração com densidade entre 2,4 e 2,8; (c) cominuição do material e análise da distribuição granulométrica; (d) caracterização tecnológica do material e produção de blocos de concreto para pavimentação; e (e) predição da geração de acidez (viabilidade ambiental). Os resultados mostraram que o rejeito de carvão utilizado neste trabalho pode ser utilizado para substituir a areia convencional como um agregado miúdo na produção de blocos de concreto para pavimentação numa proporção de até $50 \%$. Esta prática pode colaborar com a produção mais limpa de carvão mineral e reduzir a demanda de exploração de jazidas de areia.

Palavras-chave: rejeito de carvão mineral, meio ambiente, agregado miúdo, concreto, pavimentação. 


\section{Introduction}

Commercial coal production in the southern region of Brazil (comprising the Paraná, Santa Catarina, and Rio Grande do Sul states) has been occurring since the beginning of the twentieth century. Specifically in the Santa Catarina State, the production occurs at the "Irapuá", "Bonito", and mainly "Barro Branco" seams. These Gondwanic coals are classified for the major part as a high-volatile bituminous in rank. The thickness of the Barro Branco seam ranges from 1.66 to $2.27 \mathrm{~m}$, with an average value of $1.80 \mathrm{~m}$. However, net clean coal thickness is reduced to $0.47-1.48 \mathrm{~m}$, due to the presence of alternating layers of impure coal (shaley coal and coaly shale), carbonaceous shale, siltstone, and sandstones. Pyrite lenses that are several centimeters thick are also common [1]. Currently, the run-of-mine coal (ROM) is gravimetrically concentrated and almost entirely used for electricity generation. Due to the geological characteristics of the region, large amounts of solid wastes are generated. It is estimated that more than 300 million metric tons of coal waste exist in the south of Brazil, generating environmental impacts and economic costs. Regarding the Santa Catarina Coalfields, about $60 \%-65 \%$ of the ROM coal is discharged at dump deposits as waste [2]. These wastes can lead to the formation of acid mine drainage (AMD), a source of groundwater and surface water pollution [3].

Through gravity concentration processes of coal waste from Barro Branco seam, it is possible to produce three output streams: (i) a low-specific-gravity material composed of shaley coal and carbonaceous shale; (ii) an intermediate material composed of siltstone and sandstone; and (iii) a high-specific-gravity material that is rich in pyrite. Presently, there are some initiatives in Brazil to reprocess some coal waste deposits to recover part of the carbonaceous materials for energy production and, alternatively, to concentrate the pyrite for sulfuric acid production. However, the intermediatedensity material still remains, which represents $50 \%-60 \%$ in mass of the coal waste deposit and can be considered as a material for possible use in civil construction [4]. Mining wastes has been considered worldwide as a material for aggregate production $[5,6,7]$, including coal wastes (colliery spoil) [8].

Concrete paving blocks can be used in a large range of applications. The conventional source of fine aggregates for paving blocks are river sand or, alternatively, artificial sand obtained by crushing rocks [9]. However, previous research has shown that it is possible to use some wastes to produce concrete paving blocks, for example, gasification residues [10], construction and demolition waste [11,12], ceramic tile production wastes [13], marble production wastes [14], recycled glass [15], polypropylene fiber [16], crushed brick [17], electric-arc furnace dust [18], red mud [19], and fly ash [19].

According to the Brazilian standard NBR 9781 [20], the compression resistance of concrete blocks for paving should meet the minimum of $35 \mathrm{MPa}$ for pedestrian and commercial vehicles and 50 $\mathrm{MPa}$ for heavy-duty vehicles. The same limit of $35 \mathrm{MPa}$ is used by Thailand [21]. Other countries allow lower resistances, like India (30 MPa) [22], Sri Lanka (15 MPa for pedestrians) [23], and Indonesia (20 MPa) [24], or require higher resistances, like USA (55.2 $\mathrm{MPa}$ ) [25] and UK (49 MPa) [26].

Thus, the aim of this work was to study the use of coal waste to produce concrete blocks for paving. A procedure to process the coal waste with the purpose of reducing the sulfur content and changing the particle size distribution of the material to meet the specification for fine aggregates was developed. Additionally, the coal waste aggregate was characterized in terms of its chemical and physical properties. The article evaluates the main technical and environmental parameters that are involved in recycling part of the coal waste and aimed at turning it into a useful product.

\section{Materials and experimental program}

Coal waste was collected from the coal dump deposit of the "Verdinho mine," Santa Catarina State, Brazil, which extracts the Barro Branco seam. The material was submitted to a laboratory dense medium separation processing, using organic liquids, which aimed at obtaining a fraction with relative density between 2.4 and 2.8 [27]. This fraction was crushed in a roller mill and sieved to reach the particle size distribution required for fine aggregates in concrete, according to NBR 7211 [28]. The mineral-processing steps to produce the coal waste fine aggregate from coal mining tailings are presented in Figure 1.

Quartz river sand was obtained from Jacuí River, Rio Grande do Sul State. Technological characterization of both materials included particle size distribution, density measurements, visual observation in a petrographic magnifying lens, and mineral phase determination by $\mathrm{x}$-ray diffraction. Determination of sulfate and chloride ions was conducted following the procedure

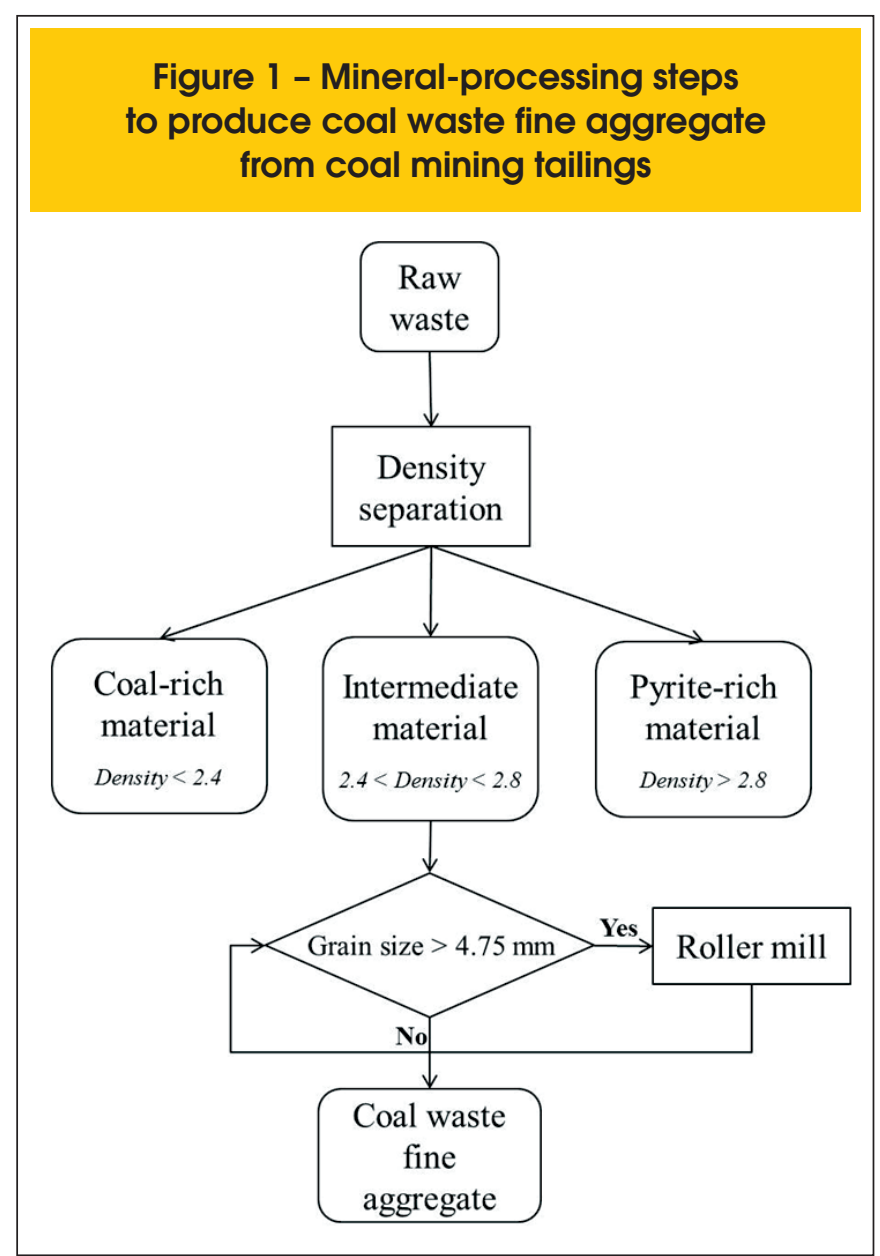




\section{Table 1 - Properties of conventional quartz sand aggregates and the coal waste fine aggregate}

\begin{tabular}{|c|c|c|}
\hline Property & Conventional river sand aggregate & Coal waste fine aggregate \\
\hline \multicolumn{3}{|c|}{ Density $\left(\mathrm{kg} / \mathrm{dm}^{3}\right)$} \\
\hline Real & 2.6 & 2.3 \\
\hline Apparent & 1.6 & 1.3 \\
\hline Particle shape & Rounded and subrounded & Angular \\
\hline Mineralogical composition & Quartz - $\mathrm{SiO}_{2}$ (major mineral phase) & $\begin{array}{l}\text { Quartz - } \mathrm{SiO}_{2} \text { (major mineral phase), } \\
\text { kaolinite - } \mathrm{Al}_{4}(\mathrm{OH})_{8}\left(\mathrm{Si}_{4} \mathrm{O}_{10}\right), \text { illite }-\left(\mathrm{K}, \mathrm{H}_{3} \mathrm{O}\right) \\
(\mathrm{Al}, \mathrm{Mg}, \mathrm{Fe})_{2}\left(\mathrm{Si}, \mathrm{Al}_{4} \mathrm{O}_{10}(\mathrm{OH})_{2^{\prime}}\left(\mathrm{H}_{2} \mathrm{O}\right)\right) \\
\text { andgypsum - } \\
\text { CaSO } 4_{4} \cdot \mathrm{H}_{2} \mathrm{O}\end{array}$ \\
\hline Sulfate ions $\left(\%\right.$ of $\left.\mathrm{SO}_{4}{ }^{2-}\right)$ & ND & 1.00 \\
\hline Chloride ions (\% of $\mathrm{Cl}$ ) & ND & ND \\
\hline \multicolumn{3}{|c|}{ Elemental composition (\%) } \\
\hline $\mathrm{C}$ & ND & 2.6 \\
\hline $\mathrm{H}$ & ND & 0.8 \\
\hline $\mathrm{N}$ & ND & 0.1 \\
\hline S & ND & 1.9 \\
\hline $\mathrm{Si}$ & 63.7 & 47.0 \\
\hline $\mathrm{Fe}$ & 1.0 & 7.5 \\
\hline Al & 1.7 & 14.0 \\
\hline $\mathrm{Mn}$ & 0.03 & 0.2 \\
\hline $\mathrm{Ca}$ & 0.4 & 4.2 \\
\hline K & 3.1 & 5.5 \\
\hline ND - not detected & & \\
\hline
\end{tabular}

described in NBR 9917 [29]. Elemental analyses of the fine aggregates were carried out by x-ray fluorescence (for $\mathrm{Si}, \mathrm{Fe}$, $\mathrm{Al}, \mathrm{Ca}$, and $\mathrm{K}$ ) and high-temperature decomposition in a CHNS analyzer (for $\mathrm{C}, \mathrm{H}, \mathrm{N}$, and $\mathrm{S}$ ). The main characteristics of both materials are summarized in Table 1.

Concrete paving blocks were produced in a vertical shaft concrete mixer. The reference trace used $5.36 \mathrm{~kg}$ of cement (CP-VARI-RS), $6.26 \mathrm{~kg}$ of coarse granitic aggregate, $14.18 \mathrm{~kg}$ of river sand aggregate, and a water/cement ratio of 0.35 . Chemical properties of the cement are presented in Table 2. Coal waste was used as a substitute for river sand aggregate, considering the following volumetric levels of substitution: $0 \%, 25 \%, 50 \%$, $75 \%$, and $100 \%$. For each level of substitution, the water/cement ratio was reestablished to provide the same consistency of concrete [30]. The concrete blocks were molded in manual press equipment with a production capacity of six blocks per cycle. The blocks were molded in the "unipaver" shape with the following dimensions: $22.5 \mathrm{~cm}$ length, $12.0 \mathrm{~cm}$ width, and $8 \mathrm{~cm}$ height (Figure 2). The technological characterization of the paving blocks included resistance to compression, abrasion resistance and water absorption. It was produced 90 blocks for compression resistance, 10 blocks for abrasion resistance, and 10 blocks for water absorption tests. The results of compression resistance are the average of six test results $(n=6$ for each level of substitution and each curing period) and the curing periods were 7,28 , and 90 days. Abrasion resistance and water absorption were carried out in two concrete blocks $(n=2)$ resulting from each level of substitution at a curing period of 28 days. The effect of the experimental parameters on these properties was

Table 2 - Chemical properties of the cement

\begin{tabular}{|cc|}
\hline Compounds & \% weight \\
\hline $\mathrm{SiO}_{3}$ & 25.12 \\
$\mathrm{Al}_{2} \mathrm{O}_{3}$ & 7.31 \\
$\mathrm{Fe}_{2} \mathrm{O}_{3}$ & 3.47 \\
$\mathrm{CaO}$ & 53.21 \\
$\mathrm{MgO}$ & 6.12 \\
\hline $\mathrm{K}_{2} \mathrm{O}$ & 1.47 \\
$\mathrm{Na}_{2} \mathrm{O}$ & 0.05 \\
$\mathrm{SO}_{3}$ & 2.59 \\
$\mathrm{CO}_{2}$ & 2.38 \\
\hline
\end{tabular}


evaluated statistically by using analysis of variance (ANOVA, significance level of $95 \%$ ) and the Tukey test.

Compression resistance and water absorption were carried out in accordance with the Brazilian Standard Procedures NBR 9780 [31] and NBR 9778 [32], respectively. Abrasion resistance was determined according to the CIENTEC method. The procedure consists of dividing a paving block specimen into two pieces with a diamond saw. Each piece is placed to a rotatory machineand submitted to a constant pressure of $0.06 \mathrm{MPa}$ in the presence of an abrasive powder (silicon carbide). The aim is to simulate a pathway of $500 \mathrm{~m}$. The width of the paving block was measured before and after the experiment in five positions of each paving block piece. The wear rate result, expressed in millimeters, is the mean of 10 measurements.

The acid generation potential of the raw waste, coal waste fine aggregates, and blocks with $25 \%$ and $50 \%$ substitution of river sand by coal waste fine aggregate at 28 days was measured by the traditional method of accounting for acids and bases (ABA) [33]. The objective was to determine the balance between the minerals that produce acidity (acidity potential - AP) and the minerals that consume acidity (neutralization potential - NP). The determination

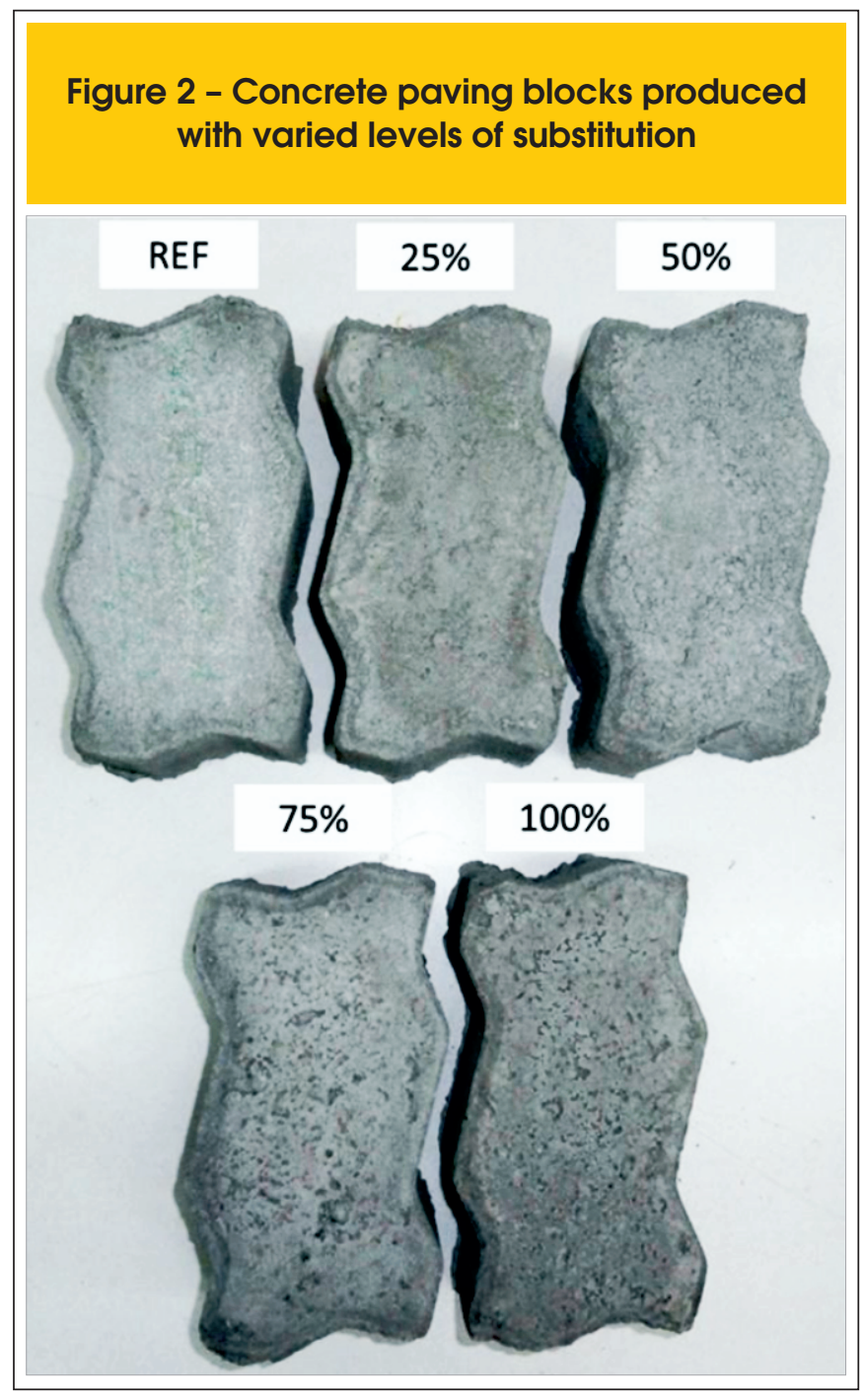

of acidity potential (AP) was carried out from the analysis of total sulfur using a CHNS analyzer. AP was calculated by the following conversion factor:

$$
\mathrm{AP}=31.25 \times \% \mathrm{~S}
$$

To determine the neutralizing potential (NP), the procedure consisted of subjecting the sample to an acidic solution followed by titration of the acid solution with sodium hydroxide (with the same concentration as that of the acid) to $\mathrm{pH}$ 7.0. The net neutralization potential (NNP) was calculated from the difference between NP and AP:

$$
\mathbf{N N P}=\mathbf{N P}-\mathbf{A P}
$$

A sample is classified as acid forming when it has NNP values less than $-20 \mathrm{CaCO}_{3}$ /t and non-acid forming when it has NNP values greater than $+20 \mathrm{CaCO}_{3} / \mathrm{t}$. Samples are classified as uncertain when their values range from -20 to $+20 \mathrm{CaCO}_{3} / \mathrm{t}$.

A kinetic test in humidity cells following the ASTM D 5744-96 [34] method was carried out to evaluate the chemical stability of the samples. The test consisted of placing $500 \mathrm{~g}$ of the material, with particle size between $6.3 \mathrm{~mm}$ and $2.0 \mathrm{~mm}$, in a column with an internal diameter of $5 \mathrm{~cm}$ and a height of $30 \mathrm{~cm}$. The test was carried out with the raw waste, coal waste fine aggregate, reference block, and block with $50 \%$ substitution of river sand by coal waste fine aggregate. During the seven-day cycle, dry air was passed through the column for the first three days and humidified air for the next three days. On the seventh day, the sample was rinsed with $500 \mathrm{~mL}$ of distilled water. The leachate was collected and analyzed for the AMD typical parameters: $\mathrm{pH}$, Eh, acidity, alkalinity, concentration of metals ( $\mathrm{Fe}, \mathrm{Al}, \mathrm{Mn}, \mathrm{Zn}$, and $\mathrm{Ca}$ ), and concentration of sulfate. The procedures followed the Standard Methods for the Examination of Water and Wastewater [35] and the results were expressed in terms of average values of twenty weeks $(n=20)$.

\section{Results and discussion}

Figure 3 presents particle size distribution of the coal waste fine aggregate as well as the river sand. Both materials have their size distribution from 0.15 to $4.0 \mathrm{~mm}$. However, the $\mathrm{D}_{50}$ (grain diameter at which $50 \%$ of the mass sample is retained or passed by the sieve) of the coal waste fine aggregate was $0.4 \mathrm{~mm}$ and the $D_{50}$ of the river sand was $1.0 \mathrm{~mm}$. So, compared to the river sand used in this work the coal waste fine aggregate has a higher amount of finer particles. It can be also observed that both materials, separately, fit in the applicable zone, but not completely in optimal zone. However, the mixture composed by $50 \%$ coal waste and $50 \%$ river sand allows a particle size distribution entirely inside the optimal zone as prescribed by NBR 7211 [28].

The $\mathrm{x}$-ray pattern of coal waste and the river sand applied in this work are depicted in Figure 4. The mineral fine aggregates produced from the coal waste have quartz as their major crystalline 
phase. The presence of kaolinite, illite, and gypsum was also detected as well as amorphous components. River sand aggregate is basically composed of quartz. The particles of coal waste are angular in shape, due to the rock fragmentation procedure, and grayish in color. In contrast, river sand particles are rounded/subrounded and yellowish in color (Figure 5).

The concentration of sulfate ions in the fine coal aggregate was determined to be $1.00 \%$, whereas in the river sand it were not detected $(<0.01 \%)$. Chloride ions were not detected in fine coal aggregate and river sand. Sulfate is considered to be harmful for concretes, and it is recommended that the values of sulfates and sulfides in aggregates for concrete production should not exceed the value of $1 \%$ (mass) $[36,37]$. The concentration of sulfates was sufficiently low to be used for paving blocks production. However, the concentration of total sulfur was determined as $1.9 \%$. Thus, for safety reasons, the fine aggregate produced from coal tailings should be applied in levels of river sand substitution of no more than $25 \%$ or $50 \%$.

The preparation of concrete with coal waste in all levels of substitution was simple. Coal waste particles mixed properly with river sand and allowed a mixture without sights of bleeding and segregation. However, increasing the amount of coal waste particles in the fine aggregate, more water was necessary to maintain the same consistency of fresh concrete. It was expected because coal waste particles are more angular in shape and smaller in size. Table 3 shows the main technological properties of concrete blocks for paving, while considering the different levels of substitution. It is possible to observe that, increasing the level of substitution, there is an increase in the water/cement ratio and a decrease in the cement consumption. It can be observed that concrete blocks produced with substitution levels of $25 \%$ and $50 \%$, at 28 days, statistically present behavior similar to the reference blocks $(0 \%$ substitution) in terms of compressive resistance, abrasion resistance, and water absorption.

In terms of compression resistance, most of the blocks manufactured with $0 \%, 25 \%$ and $50 \%$ substitution attained the minimum value of $35 \mathrm{MPa}$ established by NBR 9781 [20] for commercial standard vehicles. The blocks produced with substitution levels of $75 \%$ and $100 \%$ did not reach the required compression resistance. The loss in compression resistance in paving blocks with increasing levels of substitution of river sand by alternative aggregates has been observed in other situations, including crushed clay brick [11], ceramic tile waste [13], waste marble [14], and demolition materials [12]. It was also observed a small decrease, but statistically significant, in compression resistance from 28 to 90 days in the paving blocks with any amount of coal waste.

Increasing the level of substitution the abrasion resistance decreases. However, according to statistical analysis, the results were the same for the levels of substitution of $0 \%, 25 \%, 50 \%$, and $75 \%$. Blocks with $100 \%$ substitution of river sand presented significant difference compared to the others and, therefore, unsatisfactory results. Waste utilization in concrete production can be beneficial or harmful to abrasion resistance. The use of Class $F$ fly ash [38], waste foundry sand [39], ceramic sanitary ware waste

Figure 3 - Size particle distribution of raw coal waste, coal waste fine aggregate, river sand, and the mixture of sand/coal waste fine aggregate (50\%) as well the lower and upper limits described by NBR 721 1 (ZUI and ZUS are, respectively, the lower and the upper limits of the applicable zone, and ZOI and ZOS are the lower and the upper limits of the optimal zone)

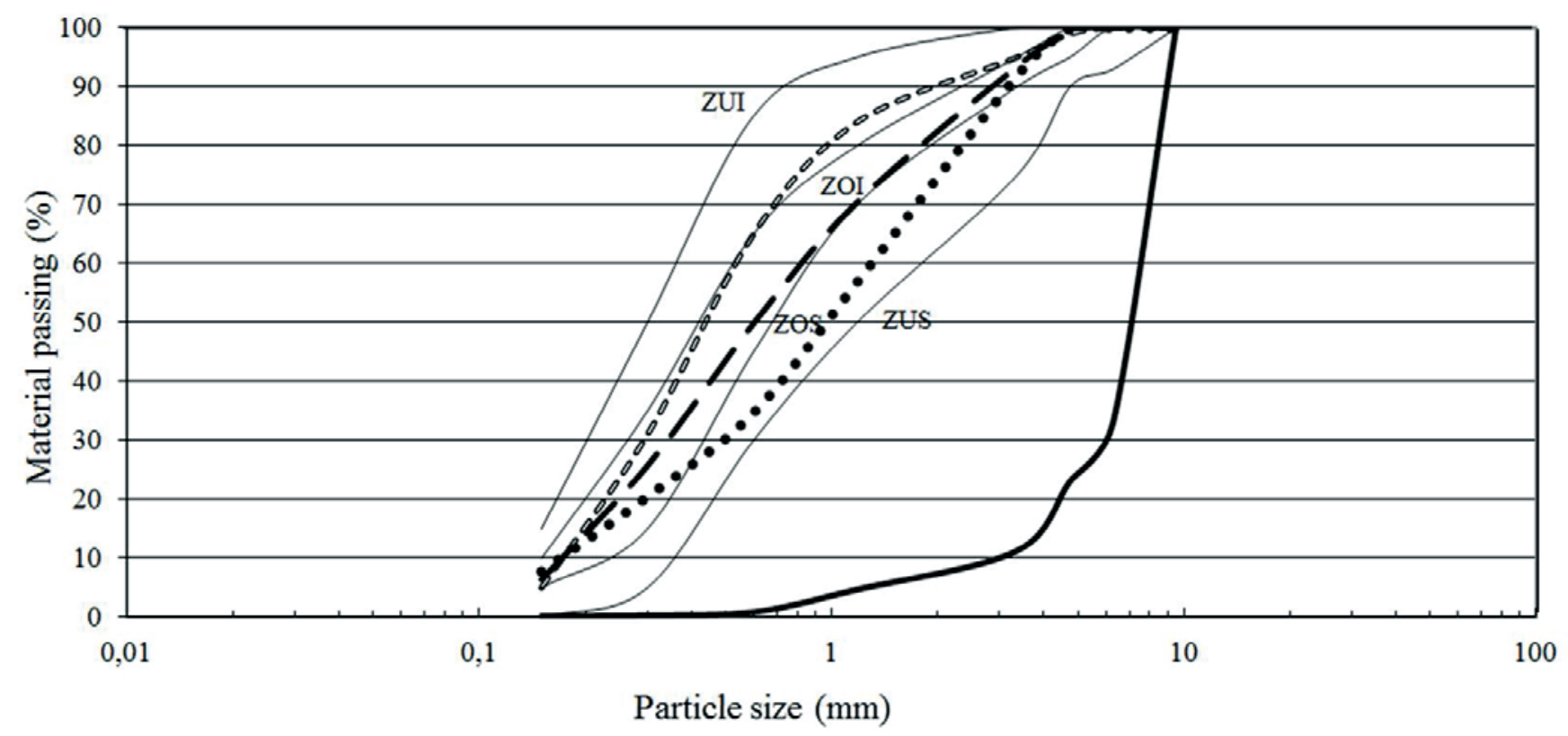

- Raw waste $=-\infty$ Coal waste fine aggregate $\cdots$ River sand - -Mixture of sand/coal waste aggregate 
[40] and shredded PET bottle waste [41] increased abrasion resistance while fly ash [42,43,44] and bottom ash [45] decreased abrasion resistance.

In terms of water absorption, it was observed an increase with the substitution of river sand by coal waste. However, the increase of water absorption for blocks with $25 \%$ to $50 \%$ coal waste is very low. The values of water absorption in reference blocks and with levels of substitution of $0 \%, 25 \%$ and $50 \%$ are statistically the same while blocks with levels of substitution of $75 \%$ and $100 \%$ are statistically different. The same behavior was observed when using bottom ash [45] and recycled fine aggregates from construction and demolition waste [46]. However,

Figure 4 - X-ray diffraction patterns of coal waste fine aggregate and river sand
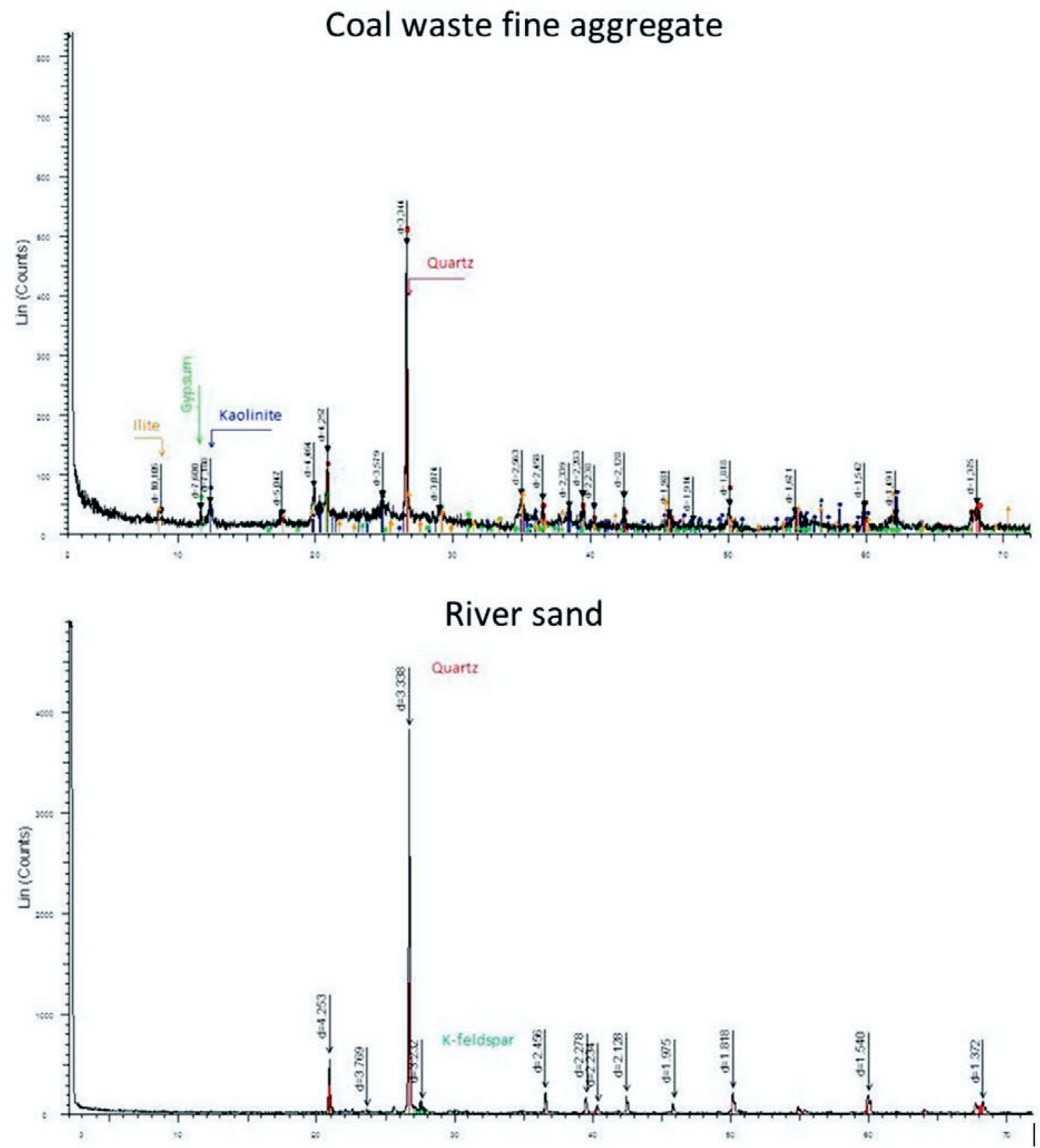


\section{Figure 5 - Pictures showing the morphological characteristics of coal waste fine aggregate and river sand}

\section{Coal waste fine aggregate}

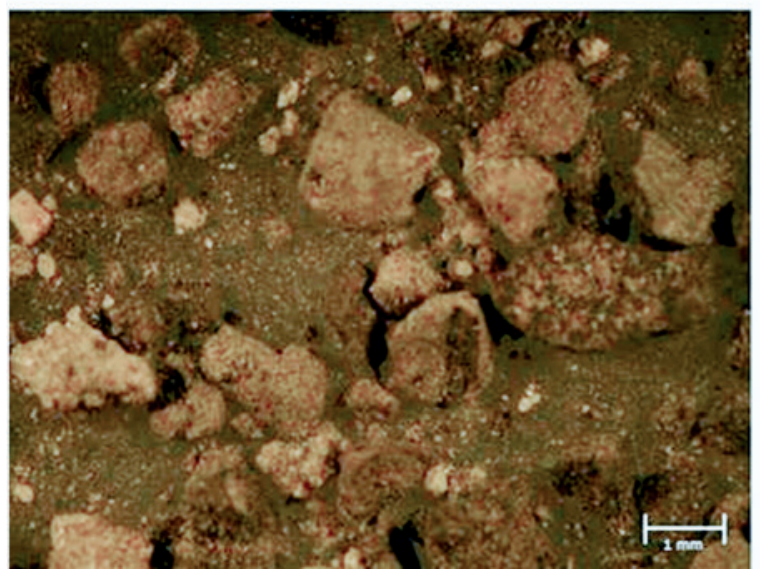

River sand

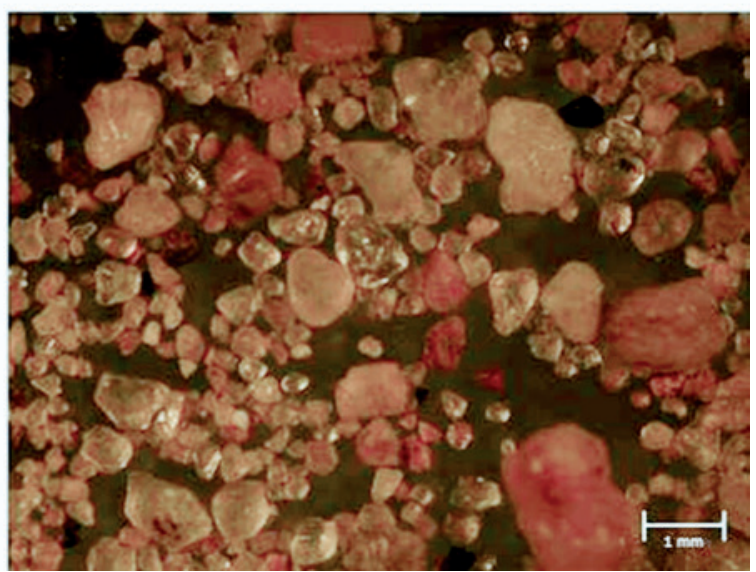

the opposite effect was observed in marble aggregates [47] and slag aggregate [48].

With respect to acid generation (Table 4), the material collected from the coal waste deposit presents a high sulfur content of $7.0 \%$. The result is an AP of $218.8 \mathrm{~kg} \mathrm{CaCO}_{3} / \mathrm{t}$, a NP of $0.0 \mathrm{~kg} \mathrm{CaCO}_{3} / \mathrm{t}$, and a NNP of $-218.8 \mathrm{~kg} \mathrm{CaCO} / \mathrm{t}$. The fraction used for fine aggregate production, with a density between 2.4 and 2.8 , exhibited a reduced acid generation potential, with a sulfur content of $1.9 \%$, an AP of $60.8 \mathrm{~kg} \mathrm{CaCO}_{3} / \mathrm{t}$, a NP of $0.0 \mathrm{~kg} \mathrm{CaCO}_{3} / \mathrm{t}$, and a NNP of $-60.8 \mathrm{CaCO}_{3} / \mathrm{t}$. The paving blocks produced with $25 \%$ and $50 \%$ substitution of river sand by coal waste fine aggregate presented a NNP that was positive and higher than $400 \mathrm{~kg} \mathrm{CaCO} / \mathrm{t}$. These results showed that the manufacture of paving blocks provided an alkaline environment and prevented acid generation.

A twenty weeks period test in humidity cells was carried out to confirm this. It can be observed in Figure 6 that the raw waste and the coal waste fine aggregate generate an acid leach. The $\mathrm{pH}$ ranged from 3.3 to 1.3 for the raw waste and from 4.0 to 2.6 for the coal waste fine aggregate. For the concrete blocks, in all situations, the water $\mathrm{pH}$ remained neutral or slightly alkaline, with the following $\mathrm{pH}$ ranges: 11.8 and 8.3 for the reference blocks and 10.3 and 7.0 for blocks with $50 \%$ substitution. These results confirm that the procedure of separation of the material rich in pyrite, followed by the encapsulation of the fine aggregate in a concrete matrix, is a

\section{Table 3 - Properties of the concrete blocks for paving}

\begin{tabular}{|c|c|c|c|c|c|}
\hline \multirow{2}{*}{ Property } & \multicolumn{5}{|c|}{ Substitution } \\
\hline & $0 \%$ & $25 \%$ & $50 \%$ & $75 \%$ & $100 \%$ \\
\hline Water/cement ratio & 0.35 & 0.37 & 0.39 & 0.43 & 0.44 \\
\hline Cement consumption $\left(\mathrm{kg} / \mathrm{m}^{3}\right)$ & 483.4 & 477.3 & 472.5 & 465.1 & 461.9 \\
\hline \multicolumn{6}{|c|}{ Elemental composition (\%) } \\
\hline 7 days & $28.1 \pm 2.8^{a}$ & $33.0 \pm 3.4^{b}$ & $34.2 \pm 1.3^{b}$ & $28.3 \pm 1.6^{a}$ & $24.8 \pm 4.6^{a}$ \\
\hline 28 days & $39.5 \pm 2.9^{a}$ & $37.6 \pm 1.6^{a}$ & $36.6 \pm 1.4^{a}$ & $31.2 \pm 2.7^{b}$ & $27.3 \pm 3.1^{\mathrm{b}}$ \\
\hline 90 days & $40.7 \pm 0.3^{a}$ & $36.2 \pm 5.3^{b}$ & $34.1 \pm 4.4^{b}$ & $29.0 \pm 3.8^{c}$ & $27.2 \pm 4.8^{c}$ \\
\hline Abrasion resistance $(\mathrm{mm}) 28$ days & $6.6 \pm 0.0^{a}$ & $7.5 \pm 1.3^{a}$ & $7.9 \pm 0.0^{a}$ & $8.1 \pm 0.5^{a}$ & $11.44 \pm 3.0^{\mathrm{b}}$ \\
\hline Water absorption (\%) 28 days & $4.9 \pm 0.0^{a}$ & $5.3 \pm 0.1^{a}$ & $5.4 \pm 0.0^{a}$ & $6.9 \pm 0.6^{b}$ & $8.0 \pm 0.8^{c}$ \\
\hline $\begin{array}{l}\text { Mass of fine aggregate of coal waste } \\
\text { consumed per } \mathrm{m}^{2} \text { of pavement }(\mathrm{kg})\end{array}$ & 0.0 & 12.1 & 24.2 & 36.4 & 48.5 \\
\hline
\end{tabular}


Table 4 - Acid generation prediction results of the raw waste, coal waste fine aggregate, and concrete paving blocks with $0 \%, 25 \%$, and $50 \%$ of substitution of river sand by the coal waste fine aggregate

\begin{tabular}{|ccccccc|}
\hline Parameter & Raw coal waste & $\begin{array}{c}\text { Coal waste } \\
\text { fine aggregate }\end{array}$ & \multicolumn{4}{c|}{ Concrete paving blocks } \\
\hline Total S $(\%)$ & 7.0 & 1.9 & 0.5 & $\mathbf{2 5 \%}$ substitution & $\mathbf{5 0 \%}$ substitution \\
\hline $\mathrm{AP}\left(\mathrm{kg} \mathrm{CaCO}_{3} / \mathrm{t}\right)$ & 218.8 & 60.8 & 15.7 & 0.4 & 0.9 \\
\hline $\mathrm{NP}\left(\mathrm{kg} \mathrm{CaCO}_{3} / \mathrm{t}\right)$ & 0.0 & 0.0 & 241.0 & 42.2 & 27.5 \\
\hline $\mathrm{NNP}$ & -218.8 & -60.8 & 225.3 & 417.8 & 488.2 \\
\hline Formation of $\mathrm{AMD}$ & Yes & Yes & No & No & 460.7 \\
\hline
\end{tabular}

successful procedure to avoid acid generation. The encapsulation of some remaining pyrite grains into the paving blocks avoids their contact with atmospheric oxygen and water, inhibiting pyrite oxidation reactions. Table 5 presents the average values of chemical parameters analyzed on the leachate considering raw coal waste particles, coal waste fine aggregate, paving blocks with $50 \%$ substitution, and reference paving blocks (100\% river sand). The leachate of raw coal waste has a low $\mathrm{pH}$ and a very high concentration of metals and sulfates. This is what happens in sulfide mining sites and it is typically named "acid rock drainage". The procedure applied to prepare the coal waste fine aggregate by density separation, allowed to reduce in $73 \%$ the concentration of pyritic sulfur. So, in this case, the leachates were less intense in terms of medium acidification and the release of metals and sulfate. Incorporating the coal waste in concrete in a proportion of $50 \%$, acidification was avoided as well the metal leaching. Comparing the leached water of the concrete produced with $100 \%$ river sand with the concrete produced with coal waste in a level of $50 \%$ substitution, the results were quite similar. However, in the latter was observed a higher amount of calcium and sulfates. Calcium and sulfate leaching can generate empty spaces in concrete structure, and therefore affect adversely compression resistance in long term.

Analyzing the results, coal waste brings benefits to adjust the particles size of the fine aggregates and the presence of quartz as the major crystalline phase reinforces coal waste as an inert material with weak potential for hydraulic activity. However, the presence of the amorphous phase as well as the minerals kaolinite, illite, gypsum, and pyrite (even at low concentrations) could affect the

\section{Figure $6-\mathrm{pH}$ values of the leachate from the humidity cells containing raw waste, coal waste fine aggregate, and concrete paving blocks (containing $0 \%$ and $50 \%$ of coal waste aggregate replacing natural sand)}

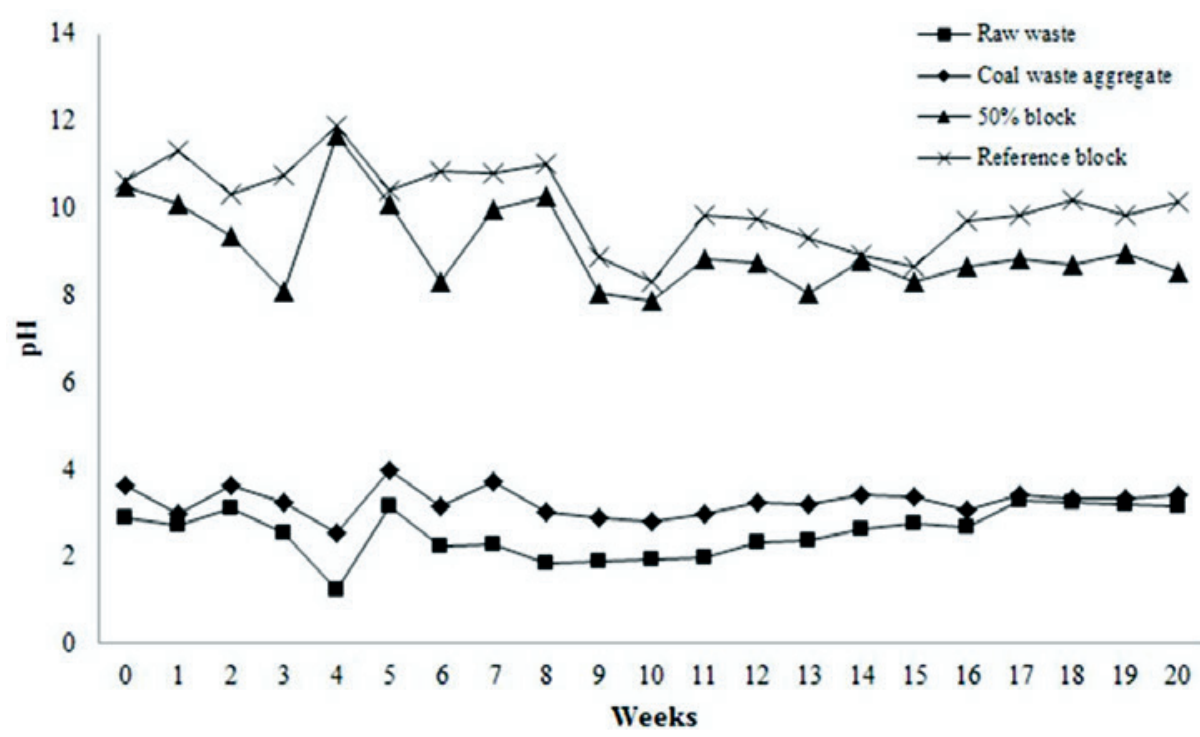


Table 5 - Average values of parameters analyzed along the kinetic test in humidity cells $(n=20)$

\begin{tabular}{|c|c|c|c|c|c|}
\hline Parameter & Unit & Raw coal waste & $\begin{array}{l}\text { Coal waste fine } \\
\text { aggregate }\end{array}$ & $\begin{array}{l}50 \% \text { substitution } \\
\text { block }\end{array}$ & $\begin{array}{l}0 \% \text { substitution } \\
\text { block }\end{array}$ \\
\hline $\mathrm{pH}$ & - & 2.5 & 3.2 & 9.0 & 10.0 \\
\hline Eh & $\mathrm{mV}$ & 721 & 682 & 443 & 417 \\
\hline Acidity & $\mathrm{mg} / \mathrm{kg} \mathrm{CaCO}{ }_{3}$ & 3542 & 186 & 9.9 & 4.0 \\
\hline Alkalinity & $\mathrm{mg} / \mathrm{kg} \mathrm{CaCO}{ }_{3}$ & 0 & 0 & 211 & 384 \\
\hline $\mathrm{Fe}$ & $\mathrm{mg} / \mathrm{L}$ & 290.8 & 8.2 & 1.1 & 1.6 \\
\hline $\mathrm{Al}$ & $\mathrm{mg} / \mathrm{L}$ & 37.5 & 8.8 & 2.7 & 3.4 \\
\hline $\mathrm{Mn}$ & $\mathrm{mg} / \mathrm{L}$ & 1.65 & 2.05 & 0.006 & 0.001 \\
\hline $\mathrm{Zn}$ & $\mathrm{mg} / \mathrm{L}$ & 0.201 & 0.176 & 0.013 & 0.008 \\
\hline $\mathrm{Ca}$ & $\mathrm{mg} / \mathrm{L}$ & 56 & 58 & 97 & 53 \\
\hline Sulfate & $\mathrm{mg} / \mathrm{L}$ & 1808 & 312 & 248 & 94 \\
\hline
\end{tabular}

long-term behavior of the paving blocks. The amorphous structure can lead to alkali-aggregate reactivity causing expansion of the aggregate in hardened concrete structure [30]. Illite can also cause expansion and cracking of concretes in such a manner that appeared analogous to alkali-silica reactivity. Expansion by illite was suggested to occur by swelling and followed by de-dolomitisation by the cement alkalis [49]. Gypsum presence in aggregates can produce false set in freshly mixed concrete and pyrite can oxidize and release sulfates. Sulfates can react after the concrete has hardened, causing expansion and cracking [30,50,51]. As mentioned before, the same water/cement ratio used in reference concrete could not be kept in concrete produced with coal waste fine aggregate. The presence of clays in a cement mixture reduces the amount of water available for the hydration reactions, decreases its workability, and alters the course of the pozzolanic reactions [52,53,54]. Problems with increased water demand with clay minerals including kaolinite and illite were observed in other works $[55,56]$. These comments are in agreement with other studies about coal waste (colliery spoils) as aggregates for concrete production. Those studies highlighted excessive wear, expansive behavior and pyrite oxidation as the main drawbacks for its use as aggregate in civil construction [7,8]. Kinnuthia et al. applied colliery spoil as fine and coarse aggregates in low and medium strength concretes [8].

Finally, with a level of substitution of $25 \%$ the demand of coal waste fine aggregate was estimated to be $12.1 \mathrm{~kg} / \mathrm{m}^{2}$ of paved area. Considering a run-of-mine coal production of $40,000 \mathrm{t}, 60 \%$ of the material is discharged as waste, and $50 \%$ of this fraction is separated between the relative densities of 2.4 and 2.8 , it is possible to produce about $12,000 \mathrm{t}$ of fine aggregates, which is sufficient to attend a paved area of about $1 \mathrm{~km}^{2}$.

\section{Conclusion}

The results showed that it was possible to process the coal waste from the carboniferous region of Santa Catarina and obtain a recycled fine aggregate that can be used in civil construction. The waste material should be submitted to a gravity separation process (with cut densities between 2.4 and 2.8 to remove the carbonaceous and pyritic fractions), which is followed by crushing in a roll mill. The material, composed mainly of siltstone and sandstone, presented a low concentration of sulfur, about $1 \%$ of sulfate, and a particle size distribution that met the specification for fine aggregates. Concrete blocks for paving produced with $25 \%$ and $50 \%$ of recycled coal waste, substituted for river sand, presented satisfactory results in terms of compression resistance. The use of coal waste as a fine aggregate for concrete block paving manufacture presents technical viability and environmental benefits. The demand for sand deposits can be minimized and a part of the coal tailings can be used, reducing the volume in coal waste deposits. We believe that this procedure can be applied to minimize the environmental problems posed by coal production in Brazil.

\section{Acknowledgments}

The authors are grateful for the financial support extended by FINEP, CAPES, CNPq, and the Brazilian Coal Network for this research.

\section{References}

[01] Kalkreuth, W., Holz, M., Mexias, A., Balbinot, M., Levandowski, J., Willett, J., Finkelman, R., Burger, H., 2010. Depositional setting, petrology and chemistry of Permian coals from the Paraná Basin: 2. South Santa Catarina Coalfield, Brazil. International Journal of Coal Geology, 84, 213-236.

[02] ABCM (Associação Brasileira do Carvão Mineral), 2012. http://www.carvaomineral.com.br/abcm/conteudo/gm_estatisticas/estatisticas_2011.pdf. Accessed 23 October, 2012.

[03] Silva, R.D.R.; Rubio, J., 2009. Treatment of acid mine drainage (AMD) from coal mines in south Brazil. International Journal of Coal Preparation and Utilization 29, 192-202.

[04] Amaral Filho, J.R.; Schneider, I.A.H.; Brum, I.A.S.; Sampaio, C.H.; Miltzarek, G.; Schneider, C.H., 2013. Caracter- 
ização de um depósito de rejeitos para o gerenciamento integrado dos resíduos de mineração na região carbonífera de Santa Catarina, Brazil. REM. Revista Escola de Minas, 66, p.347-353.

[05] Galpern, E.I.; Pashchenko, L.V.; Bratchun, V.I., 1998. Use of mine waste rock for civil engineering purposes. Proceedings of the fifth International Symposium on Environmental Issues and Waste Management in Energy and Mineral Production, Ankara, Turkey.

[06] Tohver, T., 2010. Utilization of waste rock from oil shale mining. Oil Shale, 27, 321-330.

[07] Nixon, P.J.; Gartner, E.M., 1980. An assessment of processes for the manufacture of synthetic aggregates from colliery spoil. International Journal of Cement Composites and Lightweight Concrete, 2, 141-164

[08] Kinuthia, J.; Snelson, D.; Gailius, A., 2009. Sustainable medium-strength concrete (CS-concrete) from colliery spoil in South Wales UK. Journal of Civil Engineering and Management, 15, 149-157.

[09] American Concrete Institute - ACl, "Aggregates for Concrete," Education Bulletin E1-07, Farmington Hills, 2007, p. 29.

[10] Holt, E.; Raivio, P., 2006. Use of gasification residues in compacted concrete paving blocks. Cement and Concrete Research, 36, 441-448.

[11] Poon, C. S.; Chan, D., 2006. Paving blocks made with recycled concrete aggregate and crushed clay brick. Construction and Building Materials, 20, 569-577.

[12] Soutsos, M.N.; Tang, K.; Millard, S.G., 2011. Use of recycled demolition aggregate in precast products, phase II: Concrete paving blocks. Construction and Building Materials, 25, 3131-3143.

[13] Wattanasiriwech, D.; Saiton, A.; Wattanasiriwech, S, 2009. Paving blocks from ceramic tile production waste. Journal of Cleaner Production, 17, 1663-1668.

[14] Gencel, O.; Ozel, C.; Koksal, F.; Erdogmus, E.; MartínezBarrera, G.; Brostow, W., 2012. Properties of concrete paving blocks made with waste marble. Journal of Cleaner Production, 21, 62-70.

[15] Ling, T.C.; Poon, C.S., 2014. Use of recycled CRT funnel glass as fine aggregate in dry-mixed concrete paving blocks. Journal of Cleaner Production, 68, 209-215.

[16] Kashiyani, B.K.; Pitroda, J.; Shah, B.K., 2013. Innovative addition of polypropylene fibre in interlocking paver block to improve compressive strength. International Journal of Civil, Structural, Environmental and Infrastructure Engineering Research and Development, 3, 17-26.

[17] Jankovic, K.; Nikolic, D.; Bojovic, D., 2012. Concrete paving blocks and flags made with crushed brick as aggregate. Construction and Building Materials, 28, 659-663.

[18] Vargas, A.S.; Masuero, A.B.; Vilela, A.C.F., 2006. Investigations on the use of electric-arc furnace dust (EAFD) in pozzolan-modified Portland cement I (MP) pastes. Cement and Concrete Research, 36, 1833-1841

[19] Kumar, A.; Kumar, S., 2013. Development of paving blocks from synergistic use of red mud and fly ash using geopolymerization. Construction and Building Materials, 38, 865-871.

[20] ABNT - Associação Brasileira de Normas Técnicas NBR 9781. Peças de concreto para pavimentação - Especificação e métodos de ensaio. Rio de Janeiro, 2013.
[21] TISI Standard. Interlocking concrete paving blocks (TIS 8272531 (1988)). Thai Industrial Standards Institute. 2003.

[22] IS 15658. Precast concrete blocks for paving. India: Bureau of Indian Standards; 2006.

[23] Sri Lanka Standards Institution, Draft Sri Lanka Standard, 'Specifications for concrete paving blocks: part 1: requirements', Sri Lanka Standards Institution. 2011.

[24] SNI 03 - 0691 -1989, Bata Beton Untuk Lantai, Standard Normalisasi Indonesia. 1989.

[25] ASTM C 936. Standard specification for solid concrete interlocking paving units. Masonry test methods and specifications for the building industry, 4th ed., American Society of Testing and Materials, 2001.

[26] BSI. BS 6717-1:1993 Precast, unreinforced concrete paving blocks - requirements and test methods. London: British Standards Institution (BSI); 1993.

[27] Leonard, J.W., 1991. Coal Preparation, 5th ed. Society for Mining, Metallurgy, and Exploration, Inc. Littleton, Colorado, USA.

[28] ABNT - Associação Brasileira de Normas Técnicas. NBR 7211. Agregados para Concreto, Rio de Janeiro. 2005.

[29] ABNT - Associação Brasileira de Normas Técnicas. NBR 9917. Agregados para concreto - Determinação de sais, cloretos e sulfatos solúveis, Rio de Janeiro. 2009.

[30] Mehta, P.K. and Monteiro, P.J.M, 1993. Concrete: Structure, Properties, and Materials, 2nd ed. Prentice-Hall, Englewood Cliffs, NJ, USA.

[31] ABNT - Associação Brasileira de Normas Técnicas. NBR 9780. Peças de concreto para pavimentação determinação da resistência à compressão - Método de ensaio, Rio de Janeiro. 1987.

[32] ABNT - Associação Brasileira de Normas Técnicas. NBR 9778. Argamassa e concreto endurecidos - Determinação da absorção de água, índice de vazios e massa específica Método de ensaio, Rio de Janeiro. 2005.

[33] Environmental Protection Agency. EPA 530-R-94-036: Acid Mine Drainage Prediction., 1994. Technical document.

[34] American Society for testing and Material - ASTM. ASTM D 5744: Standard test method for accelerated weathering of solid materials using a modified humidity cell. USA, 1996.

[35] American Public Health Association (APHA), "Standard Methods for the Examination of Water and Wastewater," 21st Edition, APHA-AWWA-WEF, Washington DC, 2005.

[36] Mattus, C. H. and Gilliam, T. M. A Literature Review of Mixed Waste Components: Sensitivities and Effects upon Solidification/Stabilization in Cement-based Matrices. Oak Ridge National Laboratory, Martin Marietta Energy Systems, Inc, 1994. 118p.

[37] HRN.B.B2.010-86, Aggregate for concrete. Technical Requirements (in Croatian).

[38] Siddique, R., 2003. Effect of fine aggregate replacement with Class $\mathrm{F}$ fly ash on the abrasion resistance of concrete. Cement and Concrete Research, 33, 1877-1881.

[39] Singh, G.; Siddique, R., 2011. Effect of waste foundry sand (WFS) as partial replacement of sand on the strength, ultrasonic pulse velocity and permeability of concrete. Construction and Building Materials, 26, 416-422.

[40] Halicka, A.; Ogrodnik, P.; Zegardlo, B., 2013. Using ceramic sanitary ware waste as concrete aggregate. Construction and Building Materials, 48, 295-305. 
[41] Saikia, N.; Brito, J., 2014. Mechanical properties and abrasion behaviour of concrete containing shredded PET bottle waste as a partial substitution of natural aggregate. Construction and Building Materials, 52, 236-244.

[42] Naik, T.R.; Singh, S.S.; Hossain, M.M., 1994. Abrasion resistance of concrete as influenced by inclusion of fly ash. Cement and Concrete Research, 24, Pages 303-312.

[43] Yen, T.; Hsu, T.H.; Liu, Y.W.; Chen S.H., 2007. Influence of class $\mathrm{F}$ fly ash on the abrasion-erosion resistance of high-strength concrete. Construction and Building Materials, 458-463.

[44] Siddique, R.; Kapoor, K.; Kadri, E.H.; Bennacer, R., 2012. Effect of polyester fibres on the compressive strength and abrasion resistance of HVFA concrete. Construction and Building Materials, 29, 270-278.

[45] Siddique, R., 2013. Compressive strength, water absorption, sorptivity, abrasion resistance and permeability of self-compacting concrete containing coal bottom ash. Construction and Building Materials, 47, 1444-1450.

[46] Martínez, I.; Etxeberria, M.; Pavón, E.; Díaz, N., 2013. A comparative analysis of the properties of recycled and natural aggregate in masonry mortars. Construction and Building Materials, 49, 384-392.

[47] Gameiro, F.; Brito, J.; Silva, D.C., 2014. Durability performance of structural concrete containing fine aggregates from waste generated by marble quarrying industry. Engineering Structures, 59, 654-662.

[48] Zelić, J., 2005. Properties of concrete pavements prepared with ferrochromium slag as concrete aggregate. Cement and Concrete Research, 35, 2340-2349.

[49] Swenson, E.G. A Canadian reactive aggregate undetected by ASTM tests. ASTM Bulletin 1957;226:48-51.

[50] Lee, S.Y.; Daugherty, A.M.; Broton, D. J., 2013. Assessing Aggregates for Radiation-Shielding Concrete. Concrete International, 35, 31-38.

[51] Hewlett, P.C. (ed.), 2003. Lea's Chemistry of Cement and Concrete, 4th ed. Butterworth Heinemann, Elsevier, England.

[52] Moukwa, M.; Lewis, B.G.; Shah, S.P.; Ouyang, C., 1993. Effects of clays on fracture properties of cement-based materials. Cement and Concrete Research, 23, 711-723.

[53] Changling, H.; Makovicky, E. and Osbæck, B., 1995. Pozzolanic reaction of six principal clay minerals: activation, reactivity assessments and technological effects. Cement and Concrete Research, 25, 1691-1702.

[54] Fam, M.A.; Santamarina, J. C., 1996. Study of clay-cement slurries with mechanical and electromagnetic waves. Journal of Geotechnical Engineering, 122, 365-373.

[55] Munoz, J. F.; Tejedor, M. I.; Anderson, M. A.; Cramer, S. M., 2010. Detection of aggregate clay coatings and impacts on concrete. ACI Materials Journal, 107, 387-395.

[56] Fernandes, V.A.; Purnell, P.; Still, G.T.; Thomas, T.H., 2007. The effect of clay content in sands used for cementitious materials in developing countries. Cement and Concrete Research, 37, 751-758. 